\title{
ANALISIS KECEPATAN JATUH SEDIMEN PADA SUNGAI CIBEET, JAWA BARAT
}

\author{
Kevin Wijaya Warsito ${ }^{1}$, dan Wati Astriningsih Pranoto ${ }^{2}$ \\ ${ }^{1}$ Program Studi Sarjana Teknik Sipil, Universitas Tarumanagara, Jakarta \\ Email: kevin.32515004@stu.untar.ac.id \\ ${ }^{2}$ Program Studi Magister Teknik Sipil, Universitas Tarumanagara, Jakarta \\ Email:watip@ft.untar.ac.id
}

Masuk: 10-04-2020, revisi: 24-11-2020, diterima untuk diterbitkan: 27-02-2021

\begin{abstract}
ABSTRAK
Sungai Cibeet merupakan salah satu anak sungai dari sungai Citarum di provinsi Jawa Barat dengan panjang 101 $\mathrm{km}$. Sungai Cibeet merupakan salah satu sungai pemasok air dan sedimen ke saluran irigasi Tarum Barat atau dikenal sebagai Kalimalang. Pada penelitian ini, sampel yang digunakan berupa lumpur yang diambil di Muara Sungai Cibeet. Penelitian ini difokuskan pada kecepatan jatuh sedimen yang merupakan parameter untuk sedimentasi demi meningkatkan permodelan numerik dan pemahaman konsep dari dinamika sedimen terutama lumpur. Penelitian ini dilakukan di laboratorium Mekanika Tanah dan laboratorium Hidrolika, memakai bottom withdrawal tube, dilakukan dengan menggunakan 5 macam jenis salinitas dan 6 macam konsentrasi sedimen. Penelitian ini membandingkan antara hasil laboratorium dengan pendekatan yaitu hukum Stokes serta membandingkan hubungan antara konsentrasi sedimen dengan salinitas. Untuk salinitas didapat optimum pada saat $15 \%$, dan konsentrasi sedimen yang optimum pada saat $4700 \mathrm{ppm}$ dengan kecepatan jatuh rata-rata 37,28 $\mathrm{mm} / \mathrm{s}$. Hasil dari laboratorium tidak sesuai dengan pendekatan hukum stokes dikarenakan adanya pengaruh flokulasi dari sifat sedimen lumpur yang kohesif, sehingga menggunakan pendekatan hukum stokes tidak bisa untuk menghitung kecepatan jatuh sedimen pada lumpur.
\end{abstract}

Kata Kunci: kecepatan; konsentrasi; salinitas; sedimen

\begin{abstract}
Cibeet River is one of the branch of the Citarum river in West Java province with a length of $101 \mathrm{~km}$. Cibeet River is one of the rivers supplying water and sediment to the West Tarum irrigation channel or known as the Kalimalang. In this research, the sample used was in the form of mud taken at the Cibeet River Estuary. This research is focused on settling velocity which is a parameter for sedimentation in order to improve numerical modeling and conceptual understanding of sediment dynamics, especially mud. Sediment research is carried out in the Soil Mechanics laboratory and Hydraulics laboratory. Bottom withdrawal tube experiments were carried out using 5 types of salinity and 6 kinds of sediment concentrations. The purpose of the study was to obtain settling velocity and compare laboratory results with the Stokes law approach and compare the relationship between settling velocity with sediment concentration and salinity. The optimum salinity is obtained at $15 \%$, and the optimum sediment concentration at $4700 \mathrm{ppm}$ with an average fall speed of 37,28 $\mathrm{mm} / \mathrm{s}$. The results from the laboratory are not in accordance with the Stokes law due to the influence of flocculation from the cohesive nature of the mud sediment, so that using the Stokes law approach cannot calculate the velocity of falling sediment on the mud.
\end{abstract}

Keywords: concentration; salinity; sediment; settling velocity

\section{PENDAHULUAN}

\section{Latar belakang}

Sungai Cibeet dikenal sebagai anak sungai Citarum yang menjadi batas alami antara kabupaten Karawang dan Bekasi. Sungai ini berhulu dari Gunung Lemo, yang mengalir sepanjang $101 \mathrm{~km}$. Selain itu, Sungai Cibeet memiliki dua anak sungai yaitu, Ci Gentis dan Ci Pamingkis. Sungai Cibeet merupakan salah satu sungai pemasok air ke saluran irigasi Tarum Barat atau dikenal sebagai Kalimalang. Selain itu, Sungai Cibeet memiliki bendungan di Desa Wanajaya, 
Kecamatan Telukjambe Barat, Kabupaten Karawang untuk mengairi saluran irigasi bagi lahan pertanian seluas 7500 hektar Daerah Aliran Sungai (DAS) Cibeet merupakan sub-DAS dari DAS Citarum. Sub-Das Cibeet memiliki luas mencapai 909,24 $\mathrm{km}^{2}$. Hulu Sungai Cibeet di pegunungan perbatasan Kabupaten Cianjur dengan Kabupaten Bogor tepatnya di Desa Batulawang, Kecamatan Cipanas, Kabupaten Cianjur yang kemudian mengalir ke timur.

Aliran Sungai Cibeet tidak hanya membawa air namun juga membawa sedimen. Sedimen dan air tersebut terangkut hingga ke bagian hilir sungai yang kemudian mengalami sedimentasi pada bagian badan sungai sehingga mempengaruhi morfologi dan kondisi sungai. Sedimen pada bagian muara sungai memiliki hubungan dengan kecepatan aliran sedimen. Sedimen yang terbawa tersebut akan pula jatuh dan terjadi sedimentasi, maka pada saat tersebut dapat diketahui kecepatan jatuh sedimen (settling velocity).

Kecepatan jatuh sedimen ini merupakan parameter yang fundamental untuk sedimentasi. Hal ini adalah salah satu prioritas dalam meningkatkan permodelan numerik dan pemahaman konsep dari dinamika sedimen. Kecepatan jatuh sedimen untuk sedimen kohesif berbeda dengan sedimen non kohesif. Untuk sedimen non kohesif sudah banyak dilakukan penelitian, selain itu kecepatan jatuh sedimen kohesif masih perlu penelitian lebih lanjut. Hal ini sangat menarik untuk dilakukan penelitian pada sedimen di Sungai Cibeet.

Batasan masalah pembahasan yang dianalisis, yaitu:

a. Analisis dilakukan hanya untuk sedimen Sungai Cibeet.

b. Analisis dilakukan dengan percobaan laboratrium hidrolika dan hukum stokes.

c. Kondisi air dalam keadaan tenang.

d. Menggunakan metode bottom withdrawal tube.

e. Menggunakan 5 jenis salinitas (0\%o, 7,5\%o, 15\%o, 22,5\%o, dan 35\%o).

f. Menggunakan 6 jenis konsentrasi sedimen (400, 1300, 4700, 9600, 14500, dan 20000 ppm).

Masalah yang dikemukakan pada penelitian ini antara lain:

a. Bagaimana hasil kecepatan jatuh sedimen dengan perubahan konsentrasi sedimen.

b. Bagaimana hasil kecepatan jatuh sedimen dengan perubahan salinitas.

c. Bagaimana perbandingan kecepatan jatuh sedimen dari hukum stokes dan percobaan bottom withdrawal tube.

Tujuan penelitian ini adalah mengetahui dampak salinitas dan konsentrasi sedimen terhadap kecepatan jatuh sedimen hasil percobaan bottom withdrawal tube. Selain itu, membandingkan kecepatan jatuh sedimen dari hukum stokes dan percobaan bottom withdrawal tube.

\section{Sedimentasi}

Sedimentasi berdasarkan ilmu geologi dan statigrafi adalah proses yang berperan atas terbentuknya batuan sedimen. Selanjutnya urutan proses sedimentasi meliputi proses: pelapukan, perpindahan, desposisi, dan lithifikasi (Krumbein,1971). Proses sedimentasi dipengaruhi oleh beberapa faktor berupa ukuran dan bentuk material pembentuk sedimen, beban sedimen, dan perubahan kecepatan aliran air.

\section{Salinitas}

Salinitas dapat mempengaruhi lapisan difusi ganda yang mengelilingi partikel. Dimana bila salinitas meningkat akan mengakibatkan lapisan difusi ganda menipis. Hal ini menimbulkan gaya Van der Wals sehingga sifat kohesif menjadi lebih kuat dan akan membentuk gumpalan baru yang meningkatkan kecepatan jatuh (Krone, 1962). 


\section{Sedimen kohesif}

Sedimen kohesif adalah butiran-butiran partikel lumpur yang dapat ditemukan pada dasar maupun di badan air yang bila bergabung bersama akan membentuk unit yang lebih besar disebut floc. Proses ini sangat bergantung pada konsentrasi sedimen. Flokulasi yang terjadi juga dipengaruhi oleh kecepatan jatuh sedimen kohesif. Semakin besar konsentrasi dari flokulasi, maka semakin besar juga kecepatan jatuh sedimen, namun bila konsentrasi terlalu besar akan berakibat kecepatan jatuh sedimen yang menjadi lambat (Pranoto,2010).

\section{Kecepatan jatuh partikel (settling velocity)}

Kecepatan jatuh dapat ditentukan dengan melalui beberapa cara dan dengan beberapa ketentuan yang berlaku sehingga untuk dapat menghitung kecepatan jatuh, akan dilakukan dengan beberapa pendekatan rumus dan ada beberapa pengaruh yang mempengaruhi kecepatan jatuh. Dimana untuk rumusan kecepatan jatuh hukum stokes ada 2 yaitu:

$$
\omega=\left(\frac{4 \times g \times D \times \rho_{s}-\rho_{f}}{3 \times C_{D} \times \rho_{f}}\right)^{0.5} \text { rumus umum }\left(R_{e}>1\right)
$$

dan untuk aliran air tenang menggunakan rumus:

$$
\omega=\frac{g \times D^{2} \times\left(\rho_{s}-\rho_{f}\right)}{18 \times \mu} ;\left(R_{e}<1\right)(\text { Yang, 1996) }
$$

Keterangan :

$$
\begin{array}{ll}
\omega & =\text { kecepatan jatuh }(\mathrm{mm} / \mathrm{s}) \\
\mathrm{g} & =\text { kecepatan gravitasi }\left(\mathrm{m} \cdot \mathrm{s}^{-2}\right) \\
\mathrm{D} & =\text { diameter butiran sedimen }(\mathrm{mm}) \\
\mathrm{C}_{\mathrm{D}} & =\text { Koefisien hambatan } \\
\rho_{f} & =\text { rapat massa fluida }\left(\mathrm{kg} \cdot \mathrm{m}^{-3}\right) \\
\rho_{s} & =\text { rapat massa sedimen }\left(\mathrm{kg} \cdot \mathrm{m}^{-3}\right), \text { dan } \\
\mu & =\text { viskositas dinamik }(\mathrm{kg} / \mathrm{m} \cdot \mathrm{s})
\end{array}
$$

\section{Bottom withdrawal tube}

Bottom withdrawal tube adalah metode pendekatan untuk menghitung kecepatan jatuh sedimen (settling velocity) pada sedimen kohesif. Metode ini menggunakan tabung berdiameter $5 \mathrm{~cm}$ dengan tinggi $1 \mathrm{~m}$, dimana kedua sisi tabung terbuka dan hanya ada 1 sisi yang memiliki klep khusus untuk menutupi jalurnya air (Dearnaley, 1996). Pada ilustrasi Gambar 1 dapat menunjukkan tampak alat yang akan digunakan. 


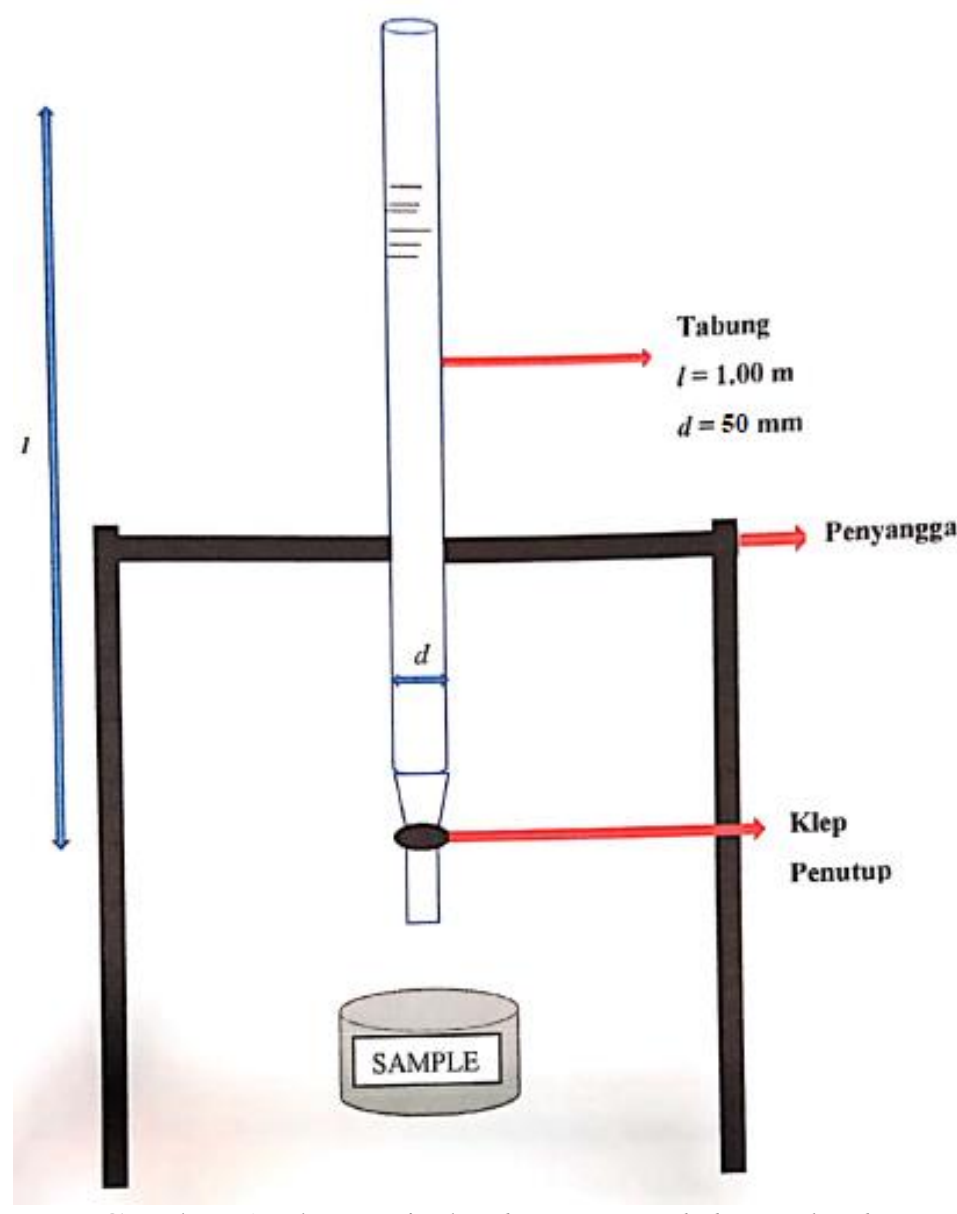

Gambar 1. Ilustrasi alat bottom withdrawal tube

\section{METODE PENELITIAN}

Sebelum dilakukannya analisis data, dilakukan pembelajaran atau studi tentang teori-teori dasar yang berhubungan dengan topik pembahasan dalam penelitian yang akan dilakukan. Teori dasar yang digunakan sebagai acuan pembelajaran dapat dicari berdasarkan berbagai macam sumber, seperti jurnal, karya ilmiah, buku referensi. Setelah memahami mengenai penelitian ini, dilakukan persiapan sampel lalu melakukan percobaan laboratorium. Kemudian hasil yang didapat dari percobaan laboratorium dibandingkan dengan pendekatan Hukum Stokes.

Untuk jenis sampel yang akan digunakan adalah sampel berupa lumpur yang di ambil dari muara Sungai Cibeet yang akan dipilah menggunakan saringan no.200. Kemudian untuk digunakan dalam perhitungan akan digunakan grafik distribusi ukuran butiran yang paling mendominasi hasil dari tes sieve analysis dan hidrometer. Berikut metode penelitian yang digambarkan pada Gambar 2. 


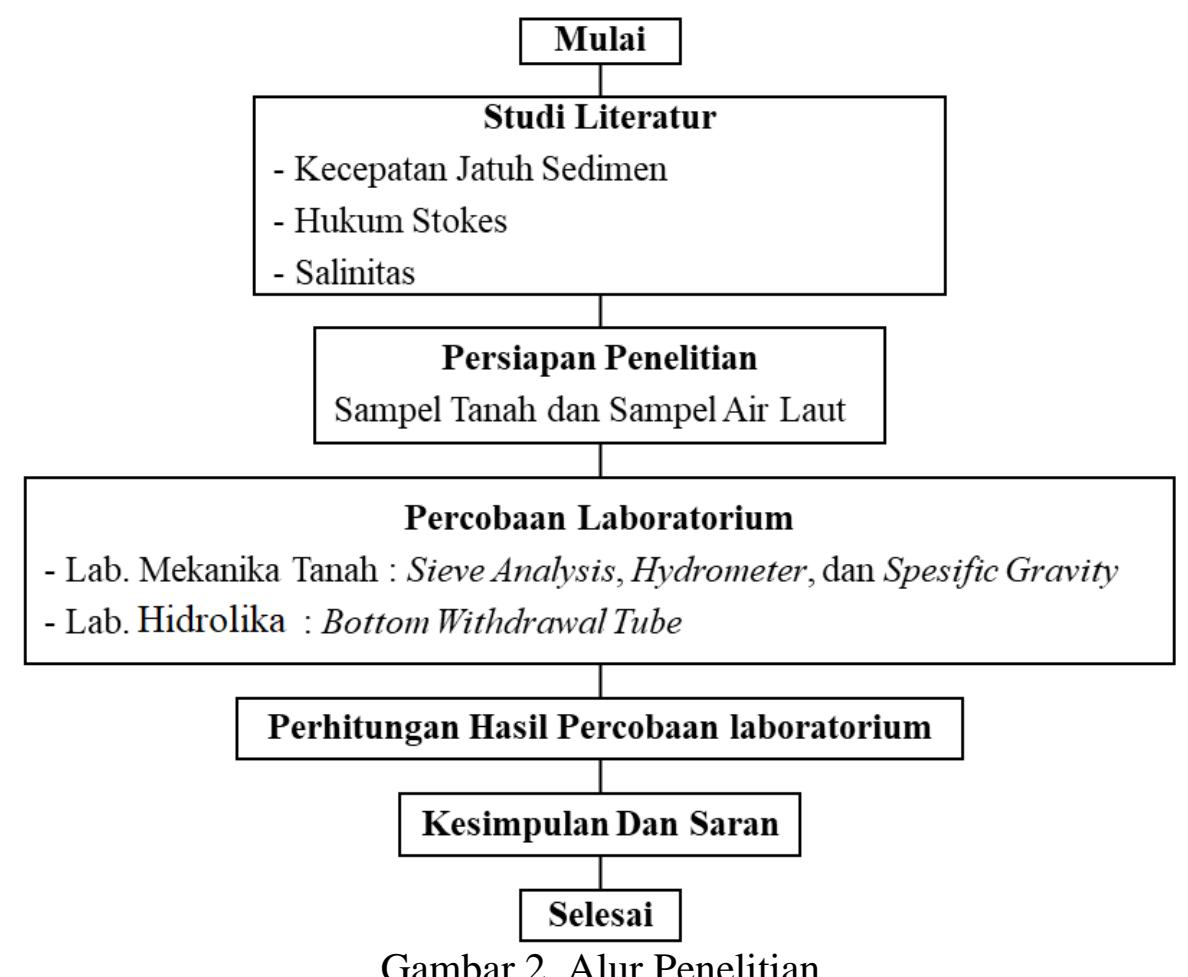

\section{HASIL DAN PEMBAHASAN}

\section{Hasil pengolahan data pada laboratorium mekanika tanah}

Dalam penelitian ini dilakukan percobaan spesific gravity, sieve analysis, dan hidrometer untuk mengetahui jenis tanah yang digunakan sebagai sampel pada penelitian ini dan data hasil pengujian laboratorium mekanika tanah tersaji dalam Tabel 1, Tabel 2, Tabel 3, dan Gambar 3.

Tabel 1. Resume spesific gravity

\begin{tabular}{|c|c|c|c|c|}
\hline \multirow{2}{*}{ No } & \multirow{2}{*}{ Item } & \multicolumn{2}{|c|}{ No Uji } & \multirow{2}{*}{ Satuan } \\
\hline & & 1 & 2 & \\
\hline 1 & No. cawan & $\mathrm{m} 126$ & m9 & - \\
\hline 2 & Berat cawan & 10 & 10,5 & gram (gr) \\
\hline 3 & Berat cawan + tanah kering & 60 & 60,5 & gram (gr) \\
\hline 4 & No. piknometer & 4 & $\mathrm{X}$ & - \\
\hline 5 & Berat piknometer, W1 & 179,2 & 184,2 & gram (gr) \\
\hline 6 & Berat piknometer + tanah kering, W2 & 229,2 & 234,2 & $\operatorname{gram}(\mathrm{gr})$ \\
\hline 7 & $\begin{array}{l}\text { Berat piknometer + tanah + air sampai garis } \\
\text { batas. W3 }\end{array}$ & 707,9 & 713,8 & $\operatorname{gram}(\mathrm{gr})$ \\
\hline 8 & $\begin{array}{l}\text { Suhu saat pengukuran berat piknometer }+ \\
\text { tanah }+ \text { air sampai garis batas }\end{array}$ & 27 & 27 & $\begin{array}{c}{ }^{\circ} \text { Celcius } \\
\left({ }^{\circ} \mathrm{C}\right)\end{array}$ \\
\hline 9 & Nilai K pada Tx & 0,9983 & 0,9983 & - \\
\hline 10 & Berat piknometer + air sampai garis batas. W4 & 676,4 & 681,1 & $\operatorname{gram}(\mathrm{gr})$ \\
\hline 11 & $\begin{array}{l}\text { Suhu saat pengukuran berat piknometer + air } \\
\text { sampai garis batas, }\left(\mathrm{Tx}^{\prime}\right)\end{array}$ & 28 & 28 & $\begin{array}{c}{ }^{\circ} \text { Celcius } \\
\left({ }^{\circ} \mathrm{C}\right)\end{array}$ \\
\hline 12 & Gs (Tx) & 2,70 & 2.89 & $\mathrm{gram} / \mathrm{cm}^{3}$ \\
\hline 13 & Gs $\left(20^{\circ} \mathrm{C}\right)$ & 2,70 & 2,89 & $\mathrm{gram} / \mathrm{cm}^{3}$ \\
\hline 14 & Rata-rata Gs & & & $\operatorname{gram} / \mathrm{cm}^{3}$ \\
\hline
\end{tabular}

Dalam Tabel 1, didapat bahwa spesific gravity untuk tanah jenis lumpur di Sungai Cibeet adalah $2,79 \mathrm{gram} / \mathrm{cm}^{3}$. 
Tabel 2. Resume sieve analysis

\begin{tabular}{|c|c|c|c|c|c|c|}
\hline No. & $\begin{array}{l}\text { Sieve } \\
\text { No }\end{array}$ & Diam. (mm) & $\begin{array}{l}\text { Wt. } \\
\text { retained }\end{array}$ & $\begin{array}{c}\text { Corr. Wt. } \\
\text { retained }\end{array}$ & $\begin{array}{c}\% \\
\text { retained }\end{array}$ & $\begin{array}{c}\% \\
\text { passsing }\end{array}$ \\
\hline 1 & 4 & 4,75 & 0 & 0,00 & $0,000 \%$ & $100,000 \%$ \\
\hline 2 & 10 & 2 & 0,1 & 0,17 & $0,034 \%$ & $99,966 \%$ \\
\hline 3 & 20 & 0,85 & 0,3 & 0,37 & $0,074 \%$ & $99,891 \%$ \\
\hline 4 & 40 & 0,425 & 1,1 & 1,17 & $0,234 \%$ & $99,657 \%$ \\
\hline 5 & 60 & 0,25 & 2,7 & 2,77 & $0,554 \%$ & $99,103 \%$ \\
\hline 6 & 140 & 0,106 & 2,2 & 2,27 & $0,454 \%$ & $98,649 \%$ \\
\hline 7 & 200 & 0,075 & 1,7 & 1,77 & $0,354 \%$ & $98,294 \%$ \\
\hline \multirow[t]{2}{*}{8} & pan & - & 0,2 & 0,27 & $0,054 \%$ & $98,240 \%$ \\
\hline & sum & & 8,3 & 8,80 & & \\
\hline
\end{tabular}

Tabel 3. Resume hidrometer

\begin{tabular}{rrrrrrrrrrrr}
\hline $\begin{array}{c}\text { Elapsed } \\
\begin{array}{c}\text { time } \\
\text { min }\end{array}\end{array}$ & Temp ${ }^{\circ} \mathrm{C}$ & $\mathrm{Ct}$ & $\mathrm{Ra}$ & $\mathrm{Rc}$ & $\begin{array}{c}\text { \% finer } \\
\text { hydro }\end{array}$ & $\mathrm{R}$ & $\mathrm{L}$ & $\mathrm{L} / \mathrm{t}$ & $\mathrm{K}$ & $\begin{array}{c}\mathrm{D} \\
(\mathrm{mm})\end{array}$ & $\%$ finer \\
\hline 1 & 30 & 3,80 & 27,00 & 35,80 & $70,31 \%$ & 32,00 & 9,20 & 9,20 & 0,0117 & 0,0355 & $69,074 \%$ \\
\hline 2 & 30 & 3,80 & 24,00 & 32,80 & $64,42 \%$ & 29,00 & 10,00 & 5,00 & 0,0117 & 0,0262 & $63,285 \%$ \\
\hline 4 & 30 & 3,80 & 20,00 & 28,80 & $56,56 \%$ & 25,00 & 11,00 & 2,75 & 0,0117 & 0,0194 & $55,568 \%$ \\
\hline 4 & 30 & 3,80 & 20,00 & 28,80 & $56,56 \%$ & 25,00 & 11,00 & 2,75 & 0,0117 & 0,0194 & $55,568 \%$ \\
\hline 8 & 30 & 3,80 & 17,00 & 25,80 & $50,67 \%$ & 22,00 & 11,80 & 1,48 & 0,0117 & 0,0142 & $49,779 \%$ \\
\hline 15 & 30 & 3,80 & 14,50 & 23,30 & $45,76 \%$ & 19,50 & 12,45 & 0,83 & 0,0117 & 0,0107 & $44,956 \%$ \\
\hline 30 & 29 & 3,05 & 12,00 & 20,05 & $39,38 \%$ & 17,00 & 13,10 & 0,44 & 0,0118 & 0,0078 & $38,685 \%$ \\
\hline 60 & 29 & 3,05 & 10,00 & 18,05 & $35,45 \%$ & 15,00 & 13,70 & 0,23 & 0,0118 & 0,0057 & $34,826 \%$ \\
\hline 120 & 28 & 2,50 & 8,00 & 15,50 & $30,44 \%$ & 13,00 & 14,20 & 0,12 & 0,0119 & 0,0041 & $29,906 \%$ \\
\hline 240 & 26 & 1,65 & 7,00 & 13,65 & $26,81 \%$ & 12,00 & 14,40 & 0,06 & 0,0122 & 0,0030 & $26,337 \%$ \\
\hline 300 & 25 & 1,30 & 7,00 & 13,30 & $26,12 \%$ & 12,00 & 14,40 & 0,05 & 0,0123 & 0,0027 & $25,661 \%$ \\
\hline
\end{tabular}

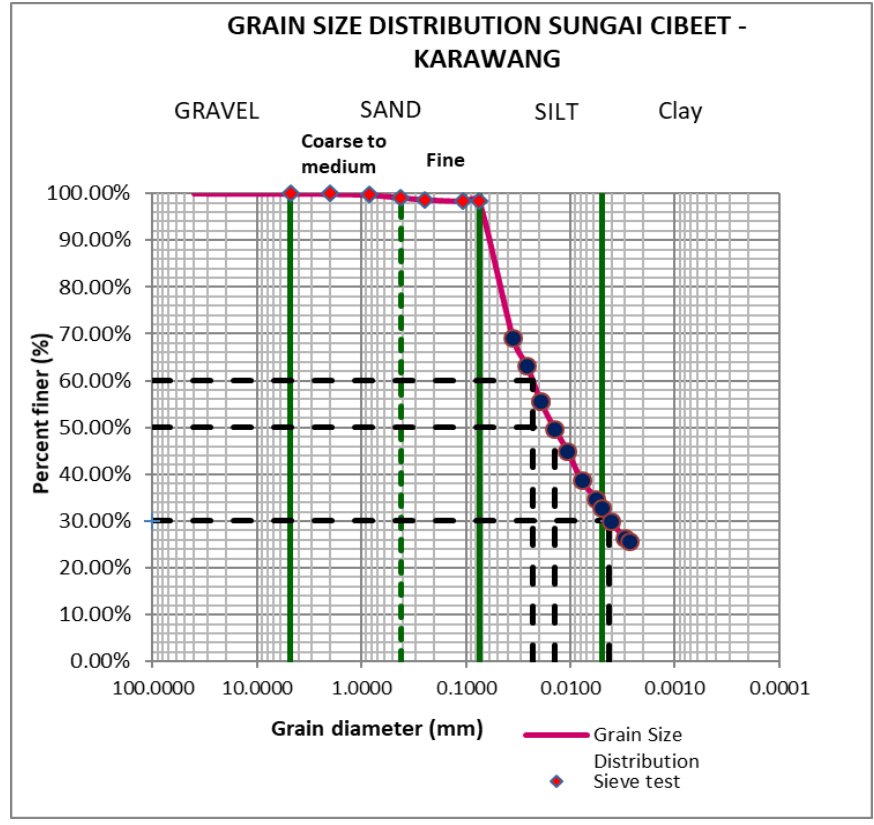

Gambar 3. Rekapitulasi distribusi butiran

Dari Gambar 3. didapat bahwa untuk $\mathrm{D}_{50}$ pada Sungai Cibeet khusus lumpur adalah 0,014 mm dengan jenis tanah silt. 
Hasil percobaan bottom withdrawal tube pada laboratorium hidrolika

Rangkuman hasil uji laboratorium hidrolika dari percobaan bottom withdrawal tube berdasarkan 5 jenis salinitas dan 6 varian konsentrasi dapat dilihat pada Tabel 4.

Tabel 4. Rekapitulasi kecepatan jatuh sedimen (settling velocity)

\begin{tabular}{|c|c|c|c|c|c|c|c|c|c|c|}
\hline \multicolumn{2}{|c|}{ Konsentrasi } & \multicolumn{3}{|c|}{400} & \multicolumn{3}{|c|}{1300} & \multicolumn{3}{|c|}{4700} \\
\hline Salinitas & Percobaan & $\begin{array}{c}\mathrm{W}_{50} \\
(\mathrm{~mm} / \mathrm{s})\end{array}$ & Suhu & $\begin{array}{c}\hat{\mathrm{W}}_{50} \\
(\mathrm{~mm} / \mathrm{s})\end{array}$ & $\begin{array}{c}\mathrm{W}_{50} \\
(\mathrm{~mm} / \mathrm{s})\end{array}$ & Suhu & $\begin{array}{c}\hat{\mathrm{W}}_{50} \\
(\mathrm{~mm} / \mathrm{s})\end{array}$ & $\begin{array}{c}\mathrm{W}_{50} \\
(\mathrm{~mm} / \mathrm{s})\end{array}$ & Suhu & $\begin{array}{c}\hat{\mathrm{W}}_{50} \\
(\mathrm{~mm} / \mathrm{s})\end{array}$ \\
\hline \multirow{2}{*}{0} & 1 & 1,80 & 29 & \multirow{2}{*}{1,64} & 2,44 & 29 & \multirow{2}{*}{2,16} & 19,90 & 30 & \multirow{2}{*}{17,66} \\
\hline & 2 & 1,48 & 28 & & 1,88 & 30 & & 15,42 & 30 & \\
\hline \multirow{2}{*}{7.5} & 1 & 1,94 & 30 & \multirow{2}{*}{1,90} & 2,37 & 29 & \multirow{2}{*}{2,25} & 12,83 & 29 & \multirow{2}{*}{12,85} \\
\hline & 2 & 1,86 & 29 & & 2,14 & 29 & & 12,86 & 29 & \\
\hline \multirow{2}{*}{15} & 1 & 2,22 & 28 & \multirow{2}{*}{2,18} & 4,08 & 28 & \multirow{2}{*}{3,85} & 30,54 & 29 & \multirow{2}{*}{37,28} \\
\hline & 2 & 2,14 & 28 & & 3,62 & 28.5 & & 44,01 & 28.5 & \\
\hline \multirow{2}{*}{22.5} & 1 & 2,07 & 29 & \multirow{2}{*}{2,03} & 1,98 & 29 & \multirow{2}{*}{2,49} & 19,92 & 28 & \multirow{2}{*}{17,17} \\
\hline & 2 & 1,99 & 28 & & 3,01 & 28.5 & & 14,42 & 28 & \\
\hline \multirow{2}{*}{35} & 1 & 1,44 & 27 & \multirow{2}{*}{1,56} & 1,13 & 27 & \multirow{2}{*}{1,54} & 19,77 & 28 & \multirow{2}{*}{19,16} \\
\hline & 2 & 1,68 & 27 & & 1,94 & 27 & & 18,55 & 28 & \\
\hline \multicolumn{2}{|c|}{ Konsentrasi } & \multicolumn{3}{|c|}{9600} & \multicolumn{3}{|c|}{14500} & \multicolumn{3}{|c|}{20000} \\
\hline Salinitas & Percobaan & $\begin{array}{c}\mathrm{W}_{50} \\
(\mathrm{~mm} / \mathrm{s})\end{array}$ & Suhu & $\begin{array}{c}\hat{\mathrm{W}}_{50} \\
(\mathrm{~mm} / \mathrm{s})\end{array}$ & $\begin{array}{c}\mathrm{W}_{50} \\
(\mathrm{~mm} / \mathrm{s})\end{array}$ & Suhu & $\begin{array}{c}\hat{\mathrm{W}}_{50} \\
(\mathrm{~mm} / \mathrm{s})\end{array}$ & $\begin{array}{c}\mathrm{W}_{50} \\
(\mathrm{~mm} / \mathrm{s})\end{array}$ & Suhu & $\begin{array}{c}\hat{\mathrm{W}}_{50} \\
(\mathrm{~mm} / \mathrm{s})\end{array}$ \\
\hline \multirow[b]{2}{*}{0} & 1 & 9,15 & 28 & \multirow{2}{*}{9,21} & 8,93 & 29 & \multirow{2}{*}{9,62} & 7,21 & 27 & \multirow{2}{*}{7,84} \\
\hline & 2 & 9,27 & 29 & & 10,32 & 27 & & 8,47 & 27 & \\
\hline 75 & 1 & 9,86 & 30 & & 8,70 & 30 & & 8,54 & 30 & \\
\hline 1.5 & 2 & 10,96 & 30 & 10,41 & 9,55 & 29 & 9,13 & 8,78 & 28 & 8,00 \\
\hline & 1 & 17,69 & 26 & & 16,19 & 28 & & 15,32 & 28 & \\
\hline 15 & 2 & 28,88 & 26 & 23,29 & 10,84 & 28.5 & 13,51 & 13,44 & 28 & 14,38 \\
\hline & 1 & 11,95 & 29 & & 6,91 & 29 & & 13,16 & 28 & \\
\hline 22.5 & 2 & 12,58 & 29 & 12,21 & 8,16 & 28 & 1,53 & 12,13 & 28 & 12,65 \\
\hline 35 & 1 & 21,46 & 26 & & 13,33 & 27 & & 13,50 & 26 & \\
\hline 5 & 2 & 12,39 & 26 & 10,92 & 8,21 & 27 & 10,11 & 13,06 & 26 & 15,20 \\
\hline
\end{tabular}

Dari Tabel 4. dibuat hubungan antara kecepatan jatuh dan konsentrasi sedimen serta salinitas, berikut disajikan dalam Gambar 4, dan Gambar 5.

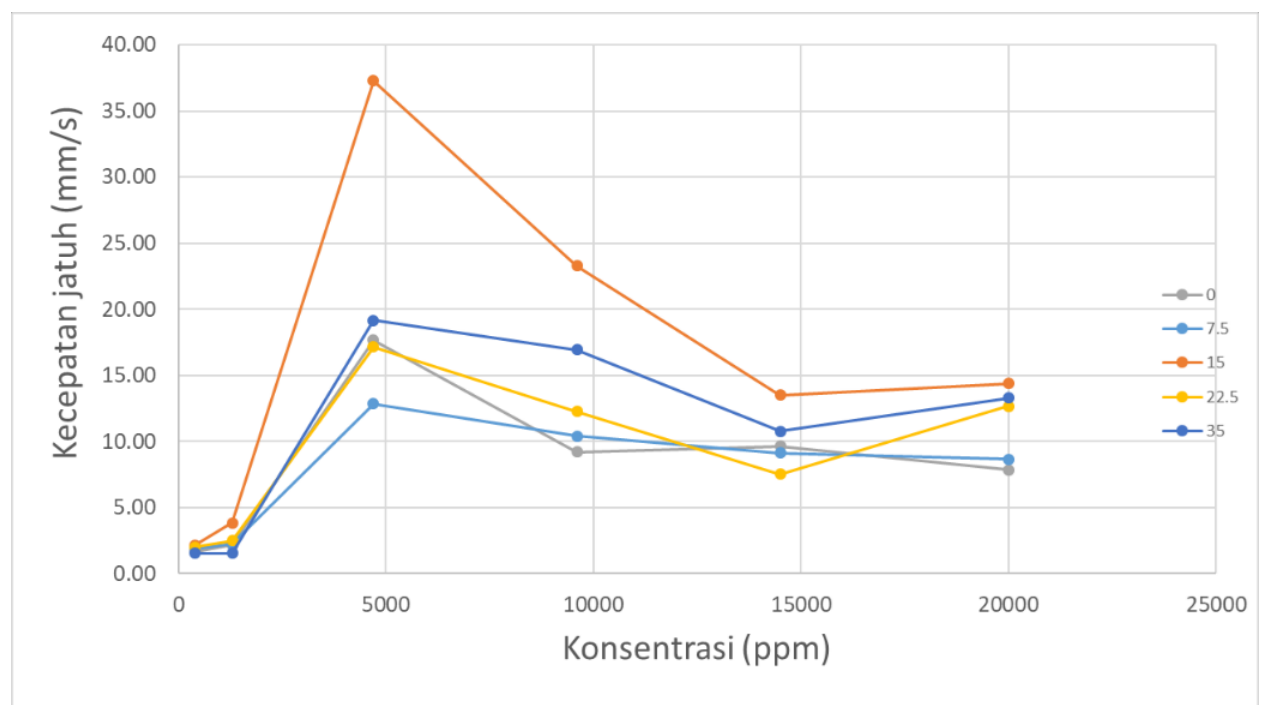

Gambar 4. Relasi antara kecepatan jatuh dan konsentrasi sedimen berdasarkan hasil percobaan 


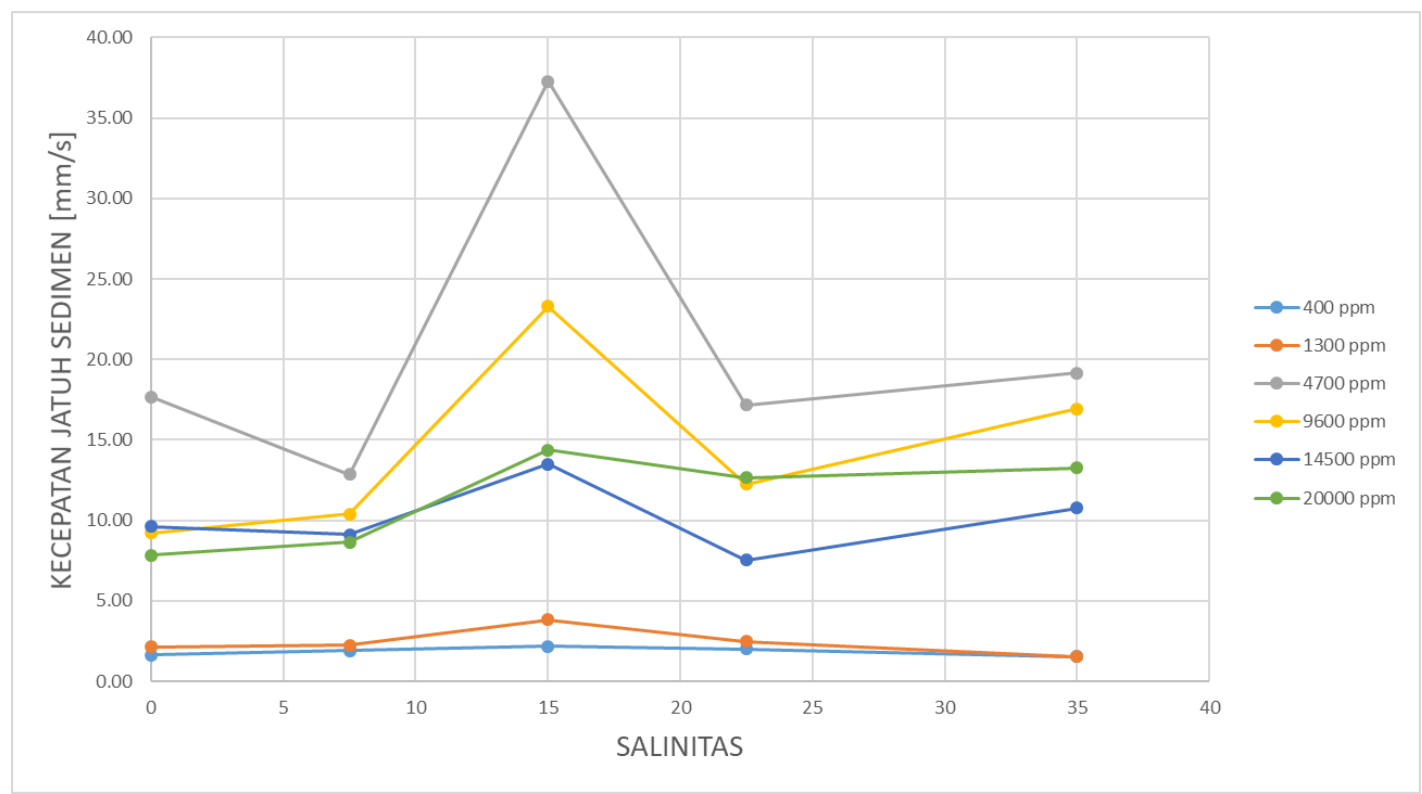

Gambar 5. Relasi antara kecepatan jatuh dan salinitas berdasarkan hasil percobaan

Dari Gambar 4. terlihat bahwa dengan bertambahnya konsentrasi sedimen maka kecepetan jatuh akan bertambah juga namun, didapat bahwa untuk titik optimum konsentrasi sedimen terletak pada 4700 ppm. Dimana setelah titik optimum, maka kecepatan jatuh disini akan menurun. Hal ini yang membuktikan ada pembentukan flocs dan terbentuknya flocs yang besar sehingga dapat mempercepat kecepatan jatuh, namun bila semakin besar flocs, justru dapat menghambat kecepatan jatuh tersebut sehingga malah terjadi penurunan kecepatan jatuh.

Dari Gambar 5. terlihat jelas bahwa dengan seiringnya bertambah salinitas maka kecepetan jatuh akan bertambah juga namun, terlihat kecepatan jatuh mencapai titik optimum pada salinitas 15\%. Dimana setelah salinitas 15\%, kecepatan jatuh justru mengalami penurunan. Hal ini membuktikan bahwa adanya pengaruh gaya Van der Wals sehingga dapat mempercepat proses flokulasi. Terbentuknya flocs yang besar dapat mempercepat kecepatan jatuh, namun bila semakin besar flocs, justru dapat menghambat kecepatan jatuh tersebut sehingga malah terjadi penurunan kecepatan jatuh.

\section{Hasil dari perhitungan hukum stokes}

Untuk perhitungan stokes akan disajikan dalam Tabel 5. dan Gambar 6.

Tabel 5. Resume Perhitungan Hukum Stokes

\begin{tabular}{cccccc}
\hline Salinity & Temperature & $\begin{array}{c}\text { Fluid } \\
\text { Density } \\
\left(\mathrm{kg} / \mathrm{m}^{3}\right)\end{array}$ & $\begin{array}{c}\text { v Kinematic } \\
\text { Viscosity } \\
* 10^{-6}\left(\mathrm{~m}^{2} / \mathrm{s}\right)\end{array}$ & $\begin{array}{c}\mu \\
\text { Dynamic } \\
\text { Viscosity } \\
* 10^{-3}(\mathrm{~kg} / \mathrm{ms})\end{array}$ & $\begin{array}{c}\text { Settling } \\
\text { Velocity } \\
(\mathrm{mm} / \mathrm{s})\end{array}$ \\
\hline 0 & 26 & 996,7 & 0,875 & 0,872 & 0,2197 \\
\hline 7,5 & 26 & 1002,231 & 0,883 & 0,885 & 0,2158 \\
\hline 15 & 26 & 1007,786 & 0,891 & 0,898 & 0,2120 \\
\hline 22,5 & 26 & 1013,362 & 0,9 & 0,912 & 0,2081 \\
\hline 35 & 26 & 1022,708 & 0,917 & 0,938 & 0,2013 \\
\hline 0 & 30 & 995,44 & 0,804 & 0,8 & 0,2396 \\
\hline 7,5 & 30 & 1000,959 & 0,811 & 0,812 & 0,2354 \\
\hline 15 & 30 & 1006,5 & 0,819 & 0,824 & 0,2312 \\
\hline 22,5 & 30 & 1012,061 & 0,827 & 0,837 & 0,2269 \\
\hline 35 & 30 & 1021,378 & 0,843 & 0,861 & 0,2194 \\
\hline
\end{tabular}




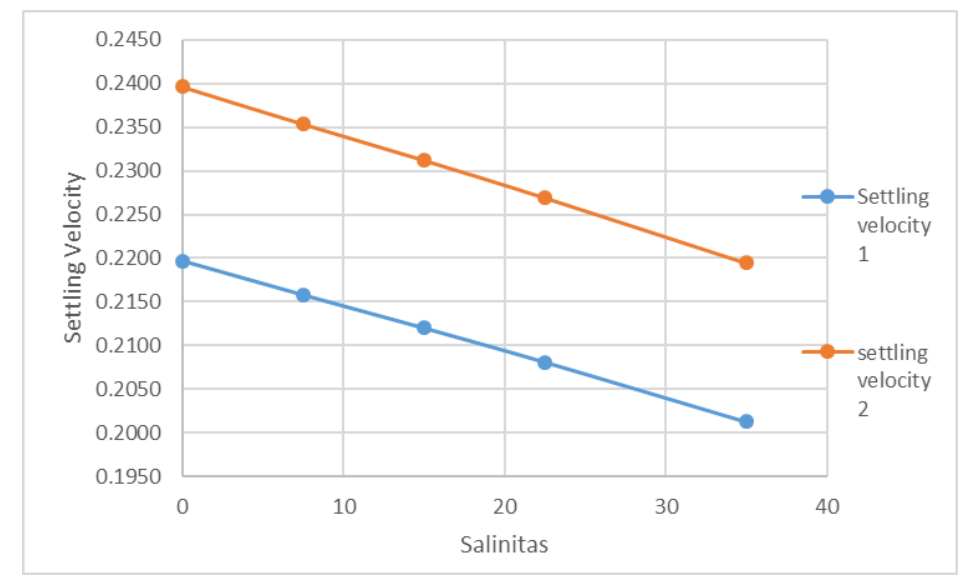

Gambar 6. Relasi antara kecepatan jatuh dan salinitas berdasarkan perhitungan stokes

Dari hasil Gambar 6. terlihat bahwa dari pengaruh bertambahnya salinitas dari hukum stokes justru semakin mengecil, hal ini bertentangan dengan dasar teori yang seharusnya semakin besar salinitas maka semakin besar juga kecepatan jatuh. Maka dari itu, hukum stokes tidak dapat digunakan dalam kondisi salinitas yang berbeda-beda dan jenis sedimen kohesif. Selain itu adanya juga pengaruh temperature dari perhitungan hukum stokes, dimana semakin besar suhu terlihat semakin besar kecepatan jatuh sedimen. Hal ini dapat menjadi salah satu faktor yang mungkin dapat dilakukan percobaan atau penelitian yang berikutnya. Dari perbandingan Gambar 5. dan Gambar 6. terlihat juga bahwa hasil dari hukum stokes sangat berbeda dari hasil percobaan bottom withdrawal tube. Hal ini yang membuktikan bahwa adanya pengaruh flokulasi dari sedimen kohesif sehingga hukum stokes tidak dapat digunakan dalam sedimen kohesif.

\section{KESIMPULAN DAN SARAN}

Pada penelitian ini, didapatkan beberapa kesimpulan sebagai berikut:

a. Kecepatan jatuh rata-rata yang tertinggi dan optimal didapat pada saat konsentrasi sedimen $4700 \mathrm{ppm}$.

b. Kecepatan jatuh rata-rata yang tertinggi dan optimal didapat pada saat salinitas $15 \%$.

c. Kecepatan jatuh hasil laboratorium dibandingkan dengan kecepatan jatuh rumus hukum stokes berbeda cukup jauh, hal ini membuktikan rumus hukum stokes tidak dapat digunakan untuk pendekatan pada jenis sedimen kohesif.

d. Seiring bertambahnya konsentrasi sedimen maka kecepatan jatuh akan semakin tinggi, namun setelah mencapai titik optimal dari konsentrasi sedimen, maka kecepatan jatuh akan menurun.

e. Seiring bertambahnya salinitas (0-15\%) maka kecepatan jatuh akan semakin tinggi, namun setelah mencapai titik optimal dari salinitas, maka kecepatan jatuh akan menurun.

Adapun saran yang dapat disampaikan untuk penelitian selanjutnya, yaitu:

a. Menyediakan waktu yang cukup untuk melakukan penelitian bottom withdrawal tube ini dikarenakan akan memakan waktu banyak untuk mengumpulkan sampel.

b. Memperbanyak percobaan akan mendapatkan hasil yang akurat dikarenakan akan ada banyak faktor yang mungkin akan mempengaruhi hasil penelitian.

c. Menambahkan variable temperature untuk penelitian berikutnya dikarenakan mungkinnya pengaruh suhu terhadap kecepatan jatuh sedimen.

d. Memperkecil range konsentrasi sedimen supaya didapat berapakah konsentrasi sedimen yang paling optimum. 


\section{REFERENSI}

Dearnaley, M. P. (1996). Direct Measurments of Settling Velocities In The Owen Tube: A Comparison With Gravimetric Analysis. Journal of Sea Research, 36(1), 41-47. https://doi.org/10.1016/S1385-1101(96)90769-8

Krone, R. B. (1962). Flume Studies of the transport of sediment in esturial shoaling processes. Berkeley: Hydraulic Engineering Laboratory and Sanitary Engineering Research Laboratory, University of California.

Krumbein, W. C., \& Sloss, L. L. (1971). Stratigraphy and sedimentation. San Fransisco: W.H. Freeman.

Pranoto, W. A. (2010). Experimental Study of Sediment Settling Velocity in Citanduy River, West Java. Civil Engineering Journal, 1(2), 88-97.

Yang, C. T. (1996). Sediment Transport: Theory And Practice. Singapore: McGraw-Hill Book Co. 